\title{
Role of P53 Expression in Pterygium in Natives from Hilly Area
}

\author{
Kaushik Sanjay ${ }^{1}$, Thakur Brijesh ${ }^{1 *}$, Kishore Sanjeev², Kala Pooja ${ }^{1}$ \\ 'Dept of Pathology, SGRRIM\&HS Dehradun \\ ${ }^{2}$ Dept of Pathology, AIIMS Rishikesh
}

\begin{abstract}
Background: Pterygium has been considered an ocular degenerative fibrovascular neoformation for long but abnormal p53 expression reinforces the theory that it is a proliferative condition like a tumor.The present study was aimed to describe the pattern of p53 immunoexpression in pterygium.

Material and Methods: We included 50 excised pterygium and 10 normal conjunctival controlspecimens, processed for histopathology and immunostaining for $\mathrm{p} 53$. Cut-off value of $\mathrm{p} 53$ expressionwas taken as $5 \%$ epithelial cell positivity.

Results: We found higher incidence of pterygium in females and statistically significant positive p53 expression in 38 cases (76\%) as compared to control group. No significant association between variations inclinical grade or histological features and abnormal p53 expression in cases and control groups was found.
\end{abstract}

Conclusion: $\mathrm{p} 53$ overexpression in pterygium suggests that pterygium is a proliferative tissue disorder.

Keywords: p53, Pterygium, Hilly

\section{Introduction}

Pterygium is a common benign wing shaped fibrovascular neoformation of ocular surface arising from bulbar conjunctiva in horizontal axis. It is thought to have been originated from limbal stem cells and has a tendency to encroach over limbus and cornea, typically on the nasal side. ${ }^{[1],[2]}$ Although it is relatively benign, it can exhibit local invasion, variable dysplasia to in situ carcinoma and early recurrence.

For long, pterygium was considered as a degenerative disorder but recent evidences suggest it to be a proliferative condition. ${ }^{[2],[3]}$ Altered p53 expression in basal limbal cells may be the cause of increased proliferation as p53 is tumor suppressor gene and critical cell cycle regulator. A few investigators also observed increased prevalence of pterygium at higher altitude..$^{[4][5]}$ The present study was aimed to describe the clinicohistopathological features and pattern of p53 immunoexpression in pterygium from a teaching hospital in Uttarakhand.

\section{Material and Methods}

This study had 60 excised pterygium specimens sent for histopathological examination. The study was approved by the Institutional Ethical Committee. Relevant history, physical and ocular examination findings including best corrected visual acuity, intraocular pressure, slit-lamp and fundus examination were recorded. Written informed consent was taken from all patients. Exclusion criteria included presence of ocular infection, pseudo/ recurrent pterygium and history of ocular trauma or surgery. Missing epithelial layer or insufficient specimen on histological examination was also ground for exclusion. On these grounds, we excluded 10 cases from this study. Eventually, we studied 50 pterygium specimens and 10 surgically excised normal conjunctival tissue as control. All cases were clinically graded into three grades depending on the extension over the cornea: grade I $(<2 \mathrm{~mm})$, grade II $(2-4$ $\mathrm{mm}$ ) and grade III ( $>4 \mathrm{~mm})$.

The excised pterygium specimen was fixed in $10 \%$ buffered formalin and sent for histopathology. After routine processing, 3-5 micron thick paraffin embeddedH\&Estained sections were analyzed for histopathological features. Extra 2-4 micron thick sections were taken on Poly-L lysine coated slides and subjected to immunohistochemical staining of p53 using primary antibodies DO7 (By cell marque: Key code-CMC45329022; at 1:300 dilution in Tris buffered saline). Reaction products were revealed with diaminobenzidine (DAB) as the chromogen and counterstaining with Harris's hematoxylin enhanced nuclear detection. Section of colonic carcinoma tissue was used as positive control and primary antibody was substituted with phosphate buffer saline (PBS) in duplicate section for negative control. Minimum 100 epithelial cells were counted and result was interpreted as "p53 positive" when it was expressed in $5 \%$ or more of the epithelial cells. 
Less than 5\% epithelial immunoreactivity was considered as negative. P53 immunoexpression was analyzed between both case and control groups using Pearson Chi-square test (with DAG software; by Mackinnon A. 2000). A p-value $<0.05$ was accepted as statistically significant.

\section{Results}

Out of 50 cases in the study, 19 cases (38\%) were males and 31 cases $(62 \%)$ were females showing overall significantly higher incidence of pterygium in females (Table 1). The mean age of presentation was $42.7 \pm 16.4$ (SD) years (age range 18-75 years). No significant difference for mean age was noticed in between study and control group.

Most common presentation was 35 cases $(70 \%)$ of grade II whereas 08 cases were clinically diagnosed as grade I. Grade III lesion was observed in 07 cases. Histological examination of pterygium showed mild chronic inflammation in $24(48 \%)$ specimens, increased vascularisation in $25(50 \%)$ and supepithelial fibrinoid changes in $42(84 \%)$ cases [Fig1a,b,c]. All three histological features revealed statistically significant difference $(p<.05)$ when compared with control group (Table1). Immunohistochemical staining revealed p53 overexpression in epithelium predominantly in basal layer [Fig1f,g]. Positive p53 expression was noticed in total 38 cases $(76 \%)$ as compared to $12(24 \%)$ negative cases $(\mathrm{p}<.05)$. All of the normal conjunctival specimens were negative for $\mathrm{p} 53$ expression [Fig1d,e], so the p53 overexpression in pterygium cases was highly significant as compared to control group (two tailed $\mathrm{p}=.0001$ ).

Table 1: Clinicohistopathological Features \& P53 Immunoexpression in Pterygium

\begin{tabular}{|c|c|c|c|}
\hline \multicolumn{2}{|r|}{ FEATURES } & CASES(50) & $\%$ \\
\hline \multicolumn{2}{|r|}{ MALE } & 19 & 38 \\
\hline \multicolumn{2}{|r|}{ FEMALE } & 31 & 62 \\
\hline \multirow{3}{*}{$\begin{array}{c}\mathrm{G} \\
\mathrm{R} \\
\mathrm{A} \\
\mathrm{D} \\
\mathrm{I} \\
\mathrm{N} \\
\mathrm{G}\end{array}$} & Grade I & 08 & 16 \\
\hline & Grade II & 35 & 64 \\
\hline & Grade III & 07 & 20 \\
\hline \multirow{2}{*}{$\begin{array}{l}\mathrm{H} \\
\mathrm{I} \\
\mathrm{S} \\
\mathrm{T}\end{array}$} & $\begin{array}{l}\text { Chronic } \\
\text { inflammation }\end{array}$ & 24 & 48 \\
\hline & $\begin{array}{l}\text { Increased } \\
\text { vascularity }\end{array}$ & 25 & 50 \\
\hline $\begin{array}{l}\text { L } \\
\text { O } \\
\text { G } \\
Y\end{array}$ & $\begin{array}{l}\text { Fibrinoid } \\
\text { changes }\end{array}$ & 42 & 84 \\
\hline $\begin{array}{l}\mathrm{I} \\
\mathrm{H} \\
\mathrm{C}\end{array}$ & P53 positive expression & 38 & 76 \\
\hline
\end{tabular}

Table 2: Comparative Analysis Of P53 Immunoexpression in Pterygium with Control Group.

\begin{tabular}{|c|c|c|c|}
\hline IHC & CASES & CONTROL & p-VALUE \\
\hline $\begin{array}{c}\text { p53 } \\
\text { POSITIVE }\end{array}$ & 38 & 00 & $\mathbf{0 0 0 0 0 5}$ \\
\hline $\begin{array}{c}\text { p53 } \\
\text { NEGATIVE }\end{array}$ & 12 & 10 & \\
\hline
\end{tabular}




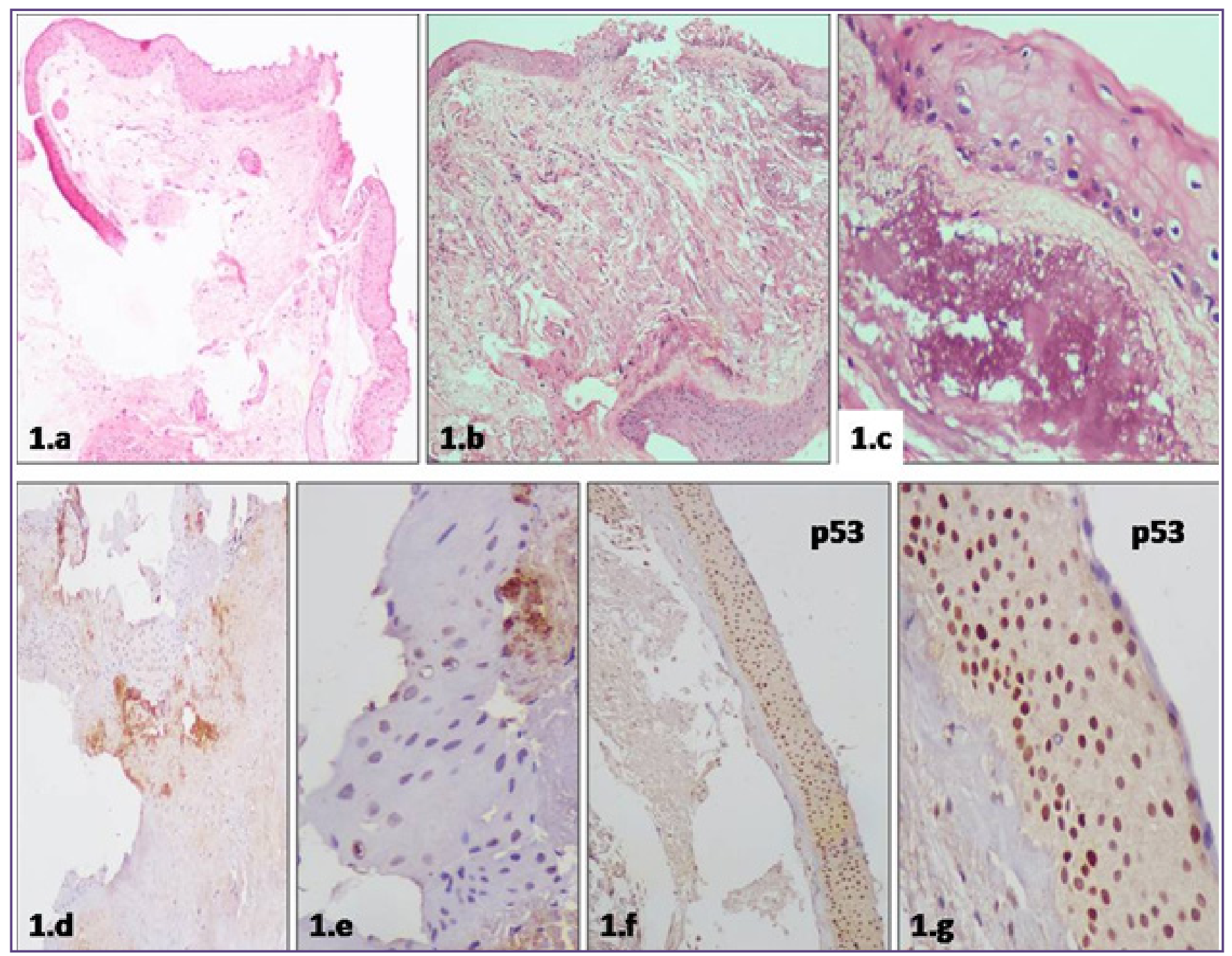

Fig. 1: a) Section showing normal control conjunctival tissue (H\&E, 100X). b) Section showing increased vascularity and mild chronic inflammation in subepithelial tissue in pterygium (H\&E, 100X), c) Section showing subepithelial fibrinoid degeneration in pterygium (H\&E, 400X), d) Section showing negative p53 expression in normal conjunctiva (IHC, 100X). e) Section showing high power view of negative p53 expression in control group (IHC, 400X). f) Section showing positive p53 expression in pterygium specimen (IHC, 100X). g) Section showing high power view of p53 overexpression in pterygium (IHC, 400X).

\section{Discussion}

Pterygium is not only a cosmetic problem for patient but also a potential blinding disease especially in advanced stage due to involvement of visual axis. It can cause irregular corneal astigmatism, corneal scarring and obscured visual axis. In terms of pathogenesis, this condition remains a puzzle. Chronic ultraviolet radiation exposure has been demonstrated as causative effect in the development of pterygium..$^{[2],[3],[6]}$ Histologically, it shows a epithelial layer with the subepithelial connective tissue showing variable degree of inflammation, neovascularisation and fibrinoid degeneration.
In our study, incidence of pterygium in females was significantally higher $(p<.05)$ that may be due to the routine socio-cultural practices in hilly areas as females usually spend more hours in outdoor daytime activities probably leading to more exposure to sunlight ultraviolet radiation for longer period. Findings similar to our study were observed by some other investigators. ${ }^{[4],[7],[8]}$ Cameron and McCarty et al. also reported the tendency of higher prevalence of pterygium with increasing age. ${ }^{[9],[10]}$

All grade I pterygium were more common in younger females whereas, majority of the higher grade pterygium cases were older individuals. It may be because of the 
increased awareness and better educational status in younger individuals or easy access to nearby health facilities. Some of the previous studies have also suggested positive correlation between pterygium incidence and poor educational or socio-economic status. ${ }^{[4],[5],[11]}$

We also analyzed three histological features; fibrinoid changes being the most common (84\%) followed by neovascularization $(50 \%)$ and chronic inflammation $(48 \%)$. None of the control specimen revealed any of these features. Our histological findings in pterygium specimens correspond to some of the previous reports as well. ${ }^{[12],[13]}$ Raizada et al. classified pterygium histpathologically into three phases; proliferative, fibromatous and atrophic sclerotic phase. ${ }^{[14]}$ They arrived at similar results as above with typical histological features in pterygium. We found no atypical features like dysplasia or metaplasia but some authors have described atypical changes and considered the possibility of pterygium to be a premalignant condition. ${ }^{[15],[16],[17]}$

The p53 protein is a tumor suppressor nuclear phosphoprotein encoded by TP53 gene located on short arm of chromosome 17. It is important for genomic stability and involved in DNA repair, cell differentiation and apoptosis. DO7 mouse monoclonal antibody reacts with an epitope in the N-terminal extreme of the p53 protein and recognizes both mutant as well as wild type p53 proteins. Epithelial cells in normal conjunctiva, p53 protein concentration is low with shorter half life while mutated or inactivated p53 gene product having longer half life is accumulated which allows its detection by immunohistochemistry easily. We have taken 5\% epithelial cell positivity as cut-off value because some previous studies considered the positive expression by taking the cut-off value ranging from $5-10 \% .{ }^{[2],[3],[18],[19]}$

In our experience, immunohistochemically overall 38 (76\%) cases stained p53 positive while none of the control specimen was $\mathrm{p} 53$ positive showing statistically significant association $(\mathrm{p}=.000005)$. Our results of $\mathrm{p} 53$ expression were much higher $(76 \%)$ than those obtained by Weinstein et al (54\%) and Ljubojević et al (44\%). ${ }^{[18],[19]}$ This may be explained by their small study group and possibly due to different geographical / environmental factors. Pelit et al studied p53 expression in two climatic regions of Turkey and found no correlation between p53 positivity and ultraviolet radiation..$^{[3]}$ The overall mean $\mathrm{p} 53$ positivity was $31.03 \%$. Similar high p53 expression in pterygium has also been reported by some other authors also. [2],[3],[18],[19] Reisman et al observed p53 gene undergoing mutation by monoallelic deletion in pterygium tissue while Tsai et al found no correlation between mutation and high p53 expression. ${ }^{[20],[21]}$
In conclusion, such high incidence of p53 overexpression in pterygium suggests a definitive role of p53 gene in its pathogenesis. It also supports the fact that pterygium is a proliferative disorder. We observed no significant association between either of the histological features or clinical grading under study and abnormal p53 expression in pterygium. In our study, no premalignant or benign neoplastic like features on histology were noticed. In view of high rate of abnormal p53 expression with significant quantitative mean p53 positivity in pterygium, there is certainly a need for larger prospective randomized multicentric studies in order to draw final opinion.

\section{Refernces}

1. Detorakis ET, Spandidos DA. Pathogenetic mechanisms and treatment options for ophthalmic pterygium: trends and perspectives (Review). Int J Mol Med 2009;23(4):439-47.

2. Zhang LW, Chen BH, Xi XH, Han QQ, Tang LS. Survivin and $\mathrm{p} 53$ expression in primary and recurrent pterygium in Chinese patients. Int J Opthalmol 2011;4(4):388-392.

3. Pelit A, Bal1 N, Akova YA, Demirhan B. P53 expression in pterygium in two climatic regions in Turkey. Indian Journal of Ophthalmology 2009;57(3):203-6.

4. Lu P, Chen X, Kang Y, Ke L, Wei X, Zhang W. Pterygium in Tibetans: a population-based study in China. Clin Experiment Opthalmol 2007;35(9):828-33.

5. Lu J, Wang Z, Lu P, Chen X, Zhang W, Shi K et al. Pterygium in an aged Mongolian population: a population-based study in China. Eye 2009;23:421-7.

6. Zhou W, Zhu Y, Zhang B, Qiu W, Yao Y. The role of ultraviolet radiation in the pathogenesis of pterygia (Review). Molecular Medicine Reports 2016;14(1):3-15.

7. $\mathrm{Wu} \mathrm{KL}, \mathrm{He} \mathrm{MG}, \mathrm{Xu} J J, \mathrm{Li}$ SZ. The epidemiological characteristic of pterygium in middle aged and the elderly in Doumen County. J Clin Ophthalmol 1999;7(1):17-18.

8. Liu H, Yang J,Zhong L. Prevalence survey on pterygium in two counties of Hainan Province. Chin J Ophthalmol 2001;37:21-3.

9. Cameron M. Geographic distribution of pterygia. Am J Ophthalmol 1964;57:880-3.

10. McCarty CA, Fu CL, Taylor HR. Epidemiology of pterygium in Victoria, Australia. Br J Ophthalmol 2000;84:289-92.

11. Luthra R, Nemesure BB, Wu SY, Xie SH, Leske MC.Barbados Eye Studies Group. Frequency and risk factors for pterygium in the Barbados Eye Study. Arch Ophthalmol 2001;119:1827-32.

12. Dzunic B, Jovanovic P, Zlatanovic G, Veselinovic D, Petrovic A, Stefanovic I. Comparative analysis of histopathological and clinical characteristics of pterygium. Vojnosanit Pregl 2010;67(2):159-65.

13. Nuhoglu F, Turna F, Uyar M, Ozdemir FE, Eltutar K. Is there a relation between histopathologic characteristics of pterygium and recurrence rates? Eur J Ophthalmol 2013;23(3):303-8. 
14. Raizada IN, Bhatnagar NK. Pinguecula and pterygium (a histopathological study). Indian J Ophthalmol 1976;24:1618 .

15. Vojnikovic B, Njiric S, Zamolo G, Toth I, Spanjol J, Coklo M. Histopathology of the pterygium in population on Croatian Island Rab. Coll Antropolo 2007;31(1):39-41.

16. Chui J, Coroneo MT, Tat LT, Crouch R, Wakefield D, Di Girolamo N. Ophthalmic pterygium A stem cell disorder with premalignant features. Am J Pathol 2011;178(2):81727.

17. Sun LL, Warrier S, Beckingsale P. Pterygium and rate of dysplasia in surgical specimens. J Clinic Experiment Ophthalmol 2011;2:166.
18. Weinstein O, Rosenthal G, Zirkin H, Monos T, Lifshitz T, Argov S. Overexpression of p53 tumor suppressor gene in pterygia. Eye 2002;16:619-21.

19. Ljubojević V, Gajanin R, Amidžić L, Vujković Z. The expression and significance of $\mathrm{p} 53$ protein and $\mathrm{Ki}-67$ protein in pterygium. Vojnosanit Pregl 2016;73(1):16-20.

20. Reisman D, McFadden JW, Lu G. Loss of heterozygosity and p53 expression in Pterygium. Cancer Lett 2004;206:7783.

21. Tsai YY, Chang KC, Lin CL, Lee H, Tsai FJ, Cheng YW. P53 expression in pterygium by immunohistochemical analysis: a series report of 127 cases and review of literature. Cornea 2005:24(5):583-6.

*Corresponding author:

Dr. Brijesh Thakur, Associate professor, Department Of Pathology, SGRRIM\&HS, Patel Nagar, Dehradun, UK, INDIA.248001

Email: drbrijeshthakur03@gmail.com

Financial or other Competing Interests: None. 